\title{
AKSESIBILITAS FISIK PUSKESMAS RAMAH LANSIA MENUJU AGE FRIENDLY CITY KOTA YOGYAKARTA
}

\author{
Oriza Husna Lativa', Winny Astuti'1, Hakimatul Mukaromah'1 \\ 1Program Studi Perencanaan Wilayah dan Kota, Fakultas Teknik, Universitas Sebelas Maret
}

\begin{abstract}
Abstrak
Kota Yogyakarta adalah kota yang mulai menerapkan Age Friendly City. Puskesmas adalah salah satu fasilitas penting dalam kosep Age Friendly City. Namun dari segi aksesibilitas fisik, puskesmas masih terkendala pada beberapa aspek. Oleh karena itu, tujuan penelitian ini adalah mengetahui aksesibilitas fisik pada puskesmas ramah lansia dalam mencapai Age Friendly City di Kota Yogyakarta. Penelitian ini menggunakan analisis skoring dan pemetaan ArcGIS 10.2. Aksesibilitas dibagi menjadi 3, yakni tinggi, sedang, dan rendah. Kajian aksesibilitas fisik pada puskesmas ramah lansia menunjukkan tingkat jangkauan pelayanan puskesmas bagi lansia adalah tinggi, sedangkan pelayanan sistem jaringan transportasi ramah lansia adalah rendah. Berdasarkan hasil analisis aspek aksesibilitas, empat dari enam skor total aspek adalah tinggi, sehingga tingkat aksesibilitas fisik pada fasilitas puskesmas ramah lansia secara keseluruhan dianggap memiliki tingkat sedang dalam mendukung penerapan Age Friendly City di Kota Yogyakarta. Penelitian ini merekomendasikan untuk memperbaiki kondisi aksesibilitas fisik puskesmas bagi lansia terutama dengan melakukan evaluasi akses pelayanan rute angkutan umum puskesmas, evaluasi letak lokasi halte terhadap puskesmas, dan perbaikan kualitas kondisi jalur pejalan kaki yang belum ramah lansia, serta penyediaan ruang parkir prioritas pada setiap sarana puskesmas agar dapat meningkatkan aksesibilitas fisik puskesmas bagi lansia.
\end{abstract}

Kata kunci: age friendly city; aksesibilitas fisik; fasilitas puskesmas; pelayanan lansia; Yogyakarta

\begin{abstract}
Yogyakarta has started to implement Age Friendly City, in which primary health care or puskesmas is one of the important supporting facilites for the concept. However, physical accessibility of the primary health care has not yet fully supported Age Friendly City concept implementation. This reserch aims at examining the physical accessibility of health care for supporting the Age Friendly City in Yogyakarta. This research utilizes scoring and mapping software ArcGIS 10.2 for analyzing the data. The results show that the range of service of primary health care for the elderly is considered having a good coverage area, but the coverage of transportation system is limited. Based on the result of data analysis four out of six scores are categorized high, so that the overall score of the physical accessibility of primary health care is classified medium in supporting the age friendly city of Yogyakarta.. This study recommends the government to conduct an evaluation process of the public transportation routes, and the location of halte, as well as improve the quality of pedestrian path and provide the priority parking spaces at each location of primary health care.
\end{abstract}

Keywords: age friendly city; elderly; physical accessibility; primary health care; Yogyakarta

\section{PENDAHULUAN}

Pelayanan kesehatan bagi lansia menurut Peraturan Menteri Kesehatan Nomor 67 Tahun 2015 tentang Penyelenggaraan Pelayanan Kesehatan Lanjut Usia di Pusat Kesehatan Masyarakat melalui satuan terkecil di masyarakat yaitu fasilitas Pusat Kesehatan Masyarakat (Puskesmas) berfokus pada pelayanan tingkat dasar bagi lanjut usia. Pelayanan tingkat dasar ini mencakup upaya promotif (peningkatan), preventif (pencegahan), kuratif (penyembuhan), dan rehabilitatif (pemulihan) untuk kesehatan lansia. Dalam mendukung kebutuhan lansia terhadap fasilitas kesehatan Puskesmas, Pemerintah Indonesia melalui Peraturan Pemerintah Nomor 43 Tahun 2004 tentang Pelaksanaan Upaya Peningkatan Kesejahteraan Sosial Lanjut Usia menjelaskan berkaitan dengan hak kemudahan aksesibilitas lansia dalam penggunaan fasilitas umum. Kemudahan dalam penggunaan fasilitas bagi lansia tersebut dapat melalui penyediaan fasilitas umum, kemudahan layanan administrasi 
fasilitas, keringanan biaya, dan kemudahan dalam perjalanan atau mobilitas lanjut usia. Lansia dapat mudah menggunakan pelayanan kesehatan puskesmas apabila didukung dengan aksesibilitas yang memadai bagi lansia yang dijelaskan oleh WHO (2007) dan WHO (2015) yaitu dalam konsep Age Friendly City atau Kota Ramah Lansia guna optimalisasi kesehatan seiring bertambahnya usia agar mewujudkan lansia yang aktif atau dikenal dengan "active ageing".

Berdasarkan SurveyMeter dan CAS UI (2013), Kota Yogyakarta menjadi salah satu dari 14 kota yang melakukan pengembangan sebagai kota ramah lansia. Hal yang menjadi pertimbangan untuk pengembangan kota ramah lansia tersebut yaitu kedudukan lansia di Kota Yogyakarta yang memiliki persentase jumlah lansia yang cukup tinggi. Berdasarkan data BPS, Kota Yogyakarta pada tahun 2013 memiliki persentase jumlah lansia sebesar 9,92\% dari jumlah penduduk total dengan Usia Harapan Hidup (UHH) mencapai 74,05 tahun. Hal ini apabila dibandingkan secara keseluruhan di Indonesia yang saat itu hanya memiliki persentase dengan Usia Harapan Hidup (UHH) 70,4 tahun (BPS Kota Yogyakarta, 2014). Sedangkan pada tahun 2019, BPS mencatat jumlah lansia di Kota Yogyakarta yang mengalami kenaikan menjadi 13,28 \% dengan Usia Harapan Hidup 74,56 tahun, namun angka tersebut kedudukannya masih berada di atas angka nasional yaitu 71,38 tahun (BPS Kota Yogyakarta, 2020).

Beberapa isu muncul dari penerapan Age Friendly City di Kota Yogyakarta, seperti fasilitas kesehatan yang diperuntukan untuk penduduk lansia di Kota Yogyakarta yaitu Pelayanan Rumah Sehat Lansia yang dalam Peraturan Walikota Yogyakarta Nomor 61 Tahun 2013 tentang Pelayanan Rumah Sehat Lansia di Kota Yogyakarta. Fasilitas kesehatan lainnya, seperti Puskesmas Santun Lansia di Kota Yogyakarta yang telah dilengkapi dengan pelayanan poli khusus lansia. Berdasarkan Keputusan Walikota Yogyakarta Nomor 450 Tahun 2019 tentang Roadmap Kota Yogyakarta Menuju Kota Ramah Lanjut Usia, Pemerintah Kota Yogyakarta memiliki target mewujudkan Kota Ramah Lansia pada Tahun 2023 sehingga pemenuhan kebutuhan dalam mengakses fasilitas kesehatan yaitu puskesmas menjadi salah satu perhatian utama untuk mendukung pelayanan kesehatan lansia yang ada di Kota Yogyakarta. Pelayanan kesehatan sudah ada di Kota Yogyakarta namun dari segi aksesibilitas fisik fasilitas puskesmasnya, jangkauan terhadap permukiman lansia perlu diperhatikan. Pendukung aksesibilitas seperti pelayanan jalur pejalan kaki pun masih banyak yang belum tertata dengan baik terutama pada fasilitas umum yang sering diakses oleh lansia (SurveyMeter dan CAS UI, 2013). Padahal penting adanya dukungan layanan berbagai macam jaringan transportasi yang seharusnya melayani keseluruhan cakupan wilayah terutama fasilitas puskesmas, guna mempermudah lansia untuk mengaksesnya.

Untuk meningkatkan kualitas lansia yang aktif atau active ageing dalam hal mendukung age friendly city, Kota Yogyakarta terus berupaya dalam memperhatikan kebutuhan kesehatan fasilitas puskesmas bagi lansia. Namun, Kota Yogyakarta tentu masih banyak yang perlu diperhatikan seperti aksesibilitas fisik fasilitas puskesmasn bagi lansia dengan kemudahan dalam menggunakan fasilitas yang disesuaikan dengan keramahan aspeknya bagi lansia. Oleh karenanya, rumusan masalah pada penelitian ini adalah "Bagaimana aksesibilitas fisik pada fasilitas puskesmas ramah lansia dalam mendukung konsep Age Friendly City di Kota Yogyakarta?". Tujuan pada penelitian ini adalah mengetahui aksesibilitas fisik pada fasilitas puskesmas ramah lansia dalam mendukung konsep Age Friendly City di Kota Yogyakarta. Penelitian ini dilakukan dengan harapan dapat memberikan manfaat informasi dan referensi mengenai aksesibilitas fasilitas puskesmas ramah lansia untuk pengembangan Kota Yogyakarta sebagai age friendly city.

\section{KAJIAN PUSTAKA}

\subsection{LANJUT USIA}

Lanjut usia atau lansia merupakan sebutan untuk seseorang yang memasuki tahap akhir dari proses penuaan dalam hidup (Indrayani dan Ronoatmodjo, 2017). Proses penuaan dengan mengalami adanya penurunan kondisi baik fisik maupun mental, bahkan akan mempengaruhi dan cenderung menghambat aktivitas dalam memenuhi kebutuhannya (Katuk dan Wowor, 2018). Dengan bertambahnya usia, lansia rentan terhadap rasa lelah, kurangnya respon terhadap lingkungan, dan menurunkan kemampuan mobilitas. Oleh karena itu kondisi lingkungan harus dapat memudahkan adaptasi lansia agar keterbatasan kemampuan tersebut teratasi dengan baik (Kurnianto, 2015). Berdasarkan Peraturan Menteri Perhubungan Nomor 98 Tahun 2017 tentang Penyediaan Aksesibilitas pada Pelayanan Jasa Transportasi Publik bagi Pengguna Jasa Berkebutuhan Khusus, lansia memiliki batasan usia yaitu lebih dari 60 tahun dan termasuk sebagai pengguna jasa 
berkebutuhan khusus dikarenakan kondisi kesehatannya memerlukan dukungan fasilitas dan perlakuan khusus agar mendapatkan kemudahan dan kemandirian dalam beraktivitas.

\subsection{FASILITAS PUSKESMAS}

Peraturan Menteri Kesehatan Nomor 67 Tahun 2015 tentang Penyelenggaraan Pelayanan Kesehatan Lanjut Usia di Pusat Kesehatan Masyarakat membahas bahwa fasilitas Pusat Kesehatan Masyarakat (Puskesmas) berfokus pada pelayanan kesehatan tingkat dasar dengan mengutamakan peningkatan kualitas kesehatan masyarakat. Hal ini harus didukung dengan adanya sumber daya manusia, bangunan, dan prasarana. Puskesmas dengan pelayanan lansia dilengkapi dengan ruang khusus lansia atau pelayanan poli lansia. Menurut Vibriyanti (2018) puskesmas yang dilengkapi dengan ruang pelayanan khusus untuk lansia adalah puskesmas santun lansia yang memberikan kemudahan pelayanan kesehatan bagi lansia.

\subsection{AGE FRIENDLY CITY}

Age Friendly City atau Kota Ramah Lansia merupakan konsep pengembangan kota mengedepankan lingkungan yang aksesibel dan inklusif, mengoptimalkan peluang untuk kesehatan, partisipasi, dan keamanan agar kualitas hidup dapat tetap tercapai seiring bertambahnya usia (WHO, 2015). Kota yang ramah bagi lansia diharapkan dapat menunjang semua kebutuhan lansia dengan keterbatasannya (Setiyanti, dkk 2019). Age Friendly City memiliki prinsip dasar sebagai berikut (WHO, 2015) :

1. Equity (kesetaraan) adalah tidak adanya kesenjangan pelayanan fasilitas baik dari aspek fisik maupun aspek sosial pelayanan. Indikatornya yaitu perbandingan antar kondisi pelayanan yang berbeda (the best-off group) (WHO, 2015). Misalnya : ramah lansia - tidak ramah lansia (jumlah pelayanan fasilitas ramah lansia lebih besar daripada pelayanan yang tidak ramah lansia)

2. Accessibility of the physical environment (aspek fisik yang aksesibel) adalah fasilitas pelayanan publik dengan perspektif desain lingkungan fasilitas pendukung yang memperhatikan keterbatasan kemampuan lansia dalam melakukan aktivitas. Indikatornya yaitu ketersediaan fasilitas pelayanan publik, akses rute moda angkutan umum, akses halte angkutan umum, lingkungan ramah berjalan kaki dengan ketersediaan jalur pejalan kaki, akses bangunan fasilitas dengan adanya ruang parkir prioritas (WHO, 2015).

3. Inclusiveness of the social environment (aspek sosial yang inklusif) adalah tidak adanya diskriminasi layanan sosial pada lansia. Indikatornya yaitu perlakuan sosial yang baik bagi lansia, ketersediaan informasi, ketersediaan layanan personal lansia, keterjangkauan biaya berdasarkan kondisi ekonomi lansia (WHO, 2015).

Menurut WHO dalam SurveyMETER dan CAS UI (2013), Age Friendly City atau Kota Ramah Lansia memiliki 8 dimensi yaitu (1) gedung dan ruang terbuka (outdoor spaces and buildings), (2) Transportasi (transportation), (3) Perumahan (housing), (4) Partisipasi Sosial (social participation), (5) Penghormatan dan Keterlibatan Sosial (respect and social inclusion), (6) Partisipasi Sipil dan Pekerjaan (civil participation and employment), (7) Komunikasi dan Informasi (communication and information), (8) Pelayanan kesehatan (community and health services).

\subsection{AKSESIBILITAS FASILITAS PUSKESMAS}

Menurut Hadi, dkk (2013), ketercapaian fasilitas kesehatan dapat dipengaruhi oleh tingkat aksesibilitas. Aksesibilitas fasilitas kesehatan oleh WHO (2007) dibahas dalam dimensi pelayanan kesehatan (community and health services), bahwa aksesibilitas pelayanan kesehatan (services accessibility) mencakup: (1) Distribusi pelayanan kesehatan merata untuk lansia, (2) Lokasi fasilitas kesehatan yang aksesibel dengan sistem jaringan transportasi, (3) Bangunan fasilitas kesehatan yang aksesibel, (4) Minimnya hambatan ekonomi untuk mendapatkan layanan kesehatan, (5) Kemudahan mendapatkan informasi pelayanan kesehatan, (6) Layanan kesehatan yang nyaman dan mudah. Dikarenakan dalam penelitian ini berfokus pada fasilitas puskesmas, maka komponen aksesibilitas pelayanan kesehatan fasilitas puskesmas yang didasarkan pada dimensi pelayanan kesehatan (community and health services) (WHO, 2007) dapat dilihat pada Tabel 1. 
Tabel 1. Aksesibilitas Fasilitas Puskesmas

\begin{tabular}{|c|c|}
\hline Aksesibilitas Fasilitas Puskesmas & Keterangan \\
\hline $\begin{array}{l}\text { Distribusi pelayanan puskesmas merata } \\
\text { untuk lansia }\end{array}$ & $\begin{array}{l}\text { Lansia mendapatkan pelayanan puskesmas didasarkan pada lokasi fasilitas puskesmas } \\
\text { yang dapat menjangkau permukiman lansia }\end{array}$ \\
\hline $\begin{array}{l}\text { Lokasi fasilitas puskesmas yang aksesibel } \\
\text { dengan sistem jaringan transportasi }\end{array}$ & $\begin{array}{l}\text { Dukungan pelayanan jaringan transportasi untuk mencapai lokasi fasilitas puskesmas, } \\
\text { seperti ketersediaan layanan moda angkutan umum, dan lain-lain. }\end{array}$ \\
\hline $\begin{array}{l}\text { Bangunan fasilitas puskesmas yang } \\
\text { aksesibel }\end{array}$ & $\begin{array}{l}\text { Kemudahan mengakses bangunan fasilitas puskesmas, seperti adanya ruang parkir } \\
\text { bagi lansia }\end{array}$ \\
\hline $\begin{array}{l}\text { Minimnya hambatan ekonomi untuk } \\
\text { mendapatkan layanan puskesmas }\end{array}$ & $\begin{array}{l}\text { Kemudahan menjangkau atau membayar biaya layanan tanpa hambatan kondisi } \\
\text { ekonomi }\end{array}$ \\
\hline $\begin{array}{l}\text { Kemudahan mendapatkan informasi } \\
\text { pelayanan puskesmas }\end{array}$ & Adanya informasi pelayanan puskesmas yang mudah diterima lansia \\
\hline $\begin{array}{l}\text { Layanan puskesmas yang nyaman dan } \\
\text { mudah }\end{array}$ & $\begin{array}{l}\text { Layanan puskesmas seperti layanan } \\
\text { kesehatan personal bagi lansia }\end{array}$ \\
\hline
\end{tabular}

Sumber: WHO, 2007

\subsection{AKSESIBILITAS FISIK PADA FASILITAS PUSKESMAS RAMAH LANSIA DALAM MENDUKUNG KONSEP AGE FRIENDLY CITY}

Berdasarkan kajian teori tentang lanjut usia, fasilitas puskesmas, age friendly city, dan aksesibilitas fasilitas puskesmas, maka aksesibilitas fasilitas puskesmas ramah lansia dalam mendukung konsep age friendly city dengan prinsip dasar age friendly city beserta indikator yang terkandung di dalamnya dapat dilihat pada Tabel 2.

Tabel 2. Aksesibilitas Fasilitas Puskesmas Ramah Lansia dalam Mendukung Konsep Age Friendly City

\begin{tabular}{ll}
$\begin{array}{c}\text { Aksesibilitas } \\
\text { Fasilitas Puskesmas }\end{array}$ & \multicolumn{1}{c}{ Prinsip yang terkandung berdasarkan WHO } \\
$(\mathbf{2 0 1 5 )}$
\end{tabular}

Accessibility of the physical environment (aspek fisik yang aksesibel)

Indikator: Ketersediaan fasilitas pelayanan publik

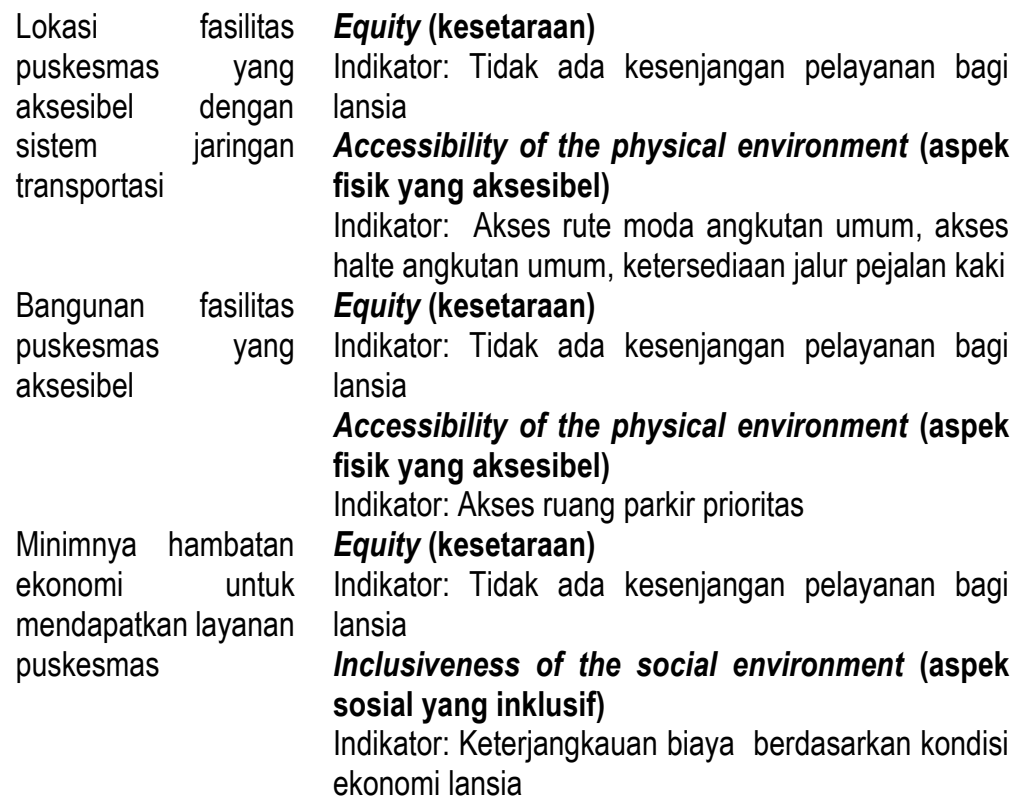

Aksesibilitas Fasilitas Puskesmas Ramah Lansia dalam Mendukung Age Friendly City

1.Jangkauan pelayanan sarana puskesmas bagi lansia

Distribusi pelayanan puskesmas merata apabila lokasi fasilitas puskesmas dapat menjangkaui permukiman lansia (WHO, 2007). Hal ini dilihat dari ketersediaan fasilitas pelayanan puskesmas dengan tidak adanya kesenjangan fasilitas puskesmas dari daya jangkauan pelayanannya bagi lansia (WHO, 2015)

2.Pelayanan sistem jaringan transportasi ramah lansia

Kemudahan akses fasilitas puskesmas dengan pelayanan sistem jaringan transportasinya bagi lansia (WHO, 2007). Hal ini dilihat dari akses fasilitas puskesmas terhadap rute moda angkutan umum, halte angkutan umum, pelayanaan jalur pejalan kaki, ruang parkir prioritas dengan tidak adanya kesenjangan fasilitas puskesmas dilihat dari pelayanan sistem jaringan transportasinya bagi lansia (WHO, 2015)

\section{Keterjangkauan biaya bagi lansia}

Minimnya hambatan ekonomi agar lansia mudah menjangkau biaya layanan dengan memperhatikan kondisi ekonomi lansia (WHO, 2007; WHO. 2015). 


\begin{tabular}{|c|c|c|}
\hline $\begin{array}{c}\text { Aksesibilitas } \\
\text { Fasilitas Puskesmas }\end{array}$ & $\begin{array}{l}\text { Prinsip yang terkandung berdasarkan WHO } \\
\qquad(2015)\end{array}$ & $\begin{array}{c}\text { Hasil: } \\
\text { Aksesibilitas Fasilitas Puskesmas Ramah } \\
\text { Lansia dalam Mendukung Age Friendly City }\end{array}$ \\
\hline $\begin{array}{l}\text { Kemudahan } \\
\text { mendapatkan } \\
\text { informasi pelayanan } \\
\text { puskesmas }\end{array}$ & $\begin{array}{l}\text { Equity (kesetaraan) } \\
\text { Indikator: Tidak ada kesenjangan pelayanan bagi } \\
\text { lansia } \\
\text { Inclusiveness of the social environment (aspek } \\
\text { sosial yang inklusif) } \\
\text { Indikator: Ketersediaan informasi }\end{array}$ & $\begin{array}{l}\text { 4.Kemudahan lansia untuk mendapatkan } \\
\text { informasi pelayanan puskesmas } \\
\text { Kemudahan mendapatkan informasi yang ditandai } \\
\text { dengan ketersediaan informasi pelayanan } \\
\text { puskesmas yang mudah diterima lansia (WHO, } \\
\text { 2007; WHO, 2015) }\end{array}$ \\
\hline $\begin{array}{l}\text { Layanan puskesmas } \\
\text { yang nyaman dan } \\
\text { mudah }\end{array}$ & $\begin{array}{l}\text { Equity (kesetaraan) } \\
\text { Indikator: Tidak ada kesenjangan pelayanan bagi } \\
\text { lansia } \\
\text { Inclusiveness of the social environment (aspek } \\
\text { sosial yang inklusif) } \\
\text { Indikator: Ketersediaan layanan personal lansia }\end{array}$ & $\begin{array}{l}\text { 5.Kenyamanan layanan puskesmas bagi lansia } \\
\text { Layanan puskesmas yang nyaman dan mudah } \\
\text { seperti perlakuan layanan petugas puskesmas } \\
\text { yang ramah dan ketersediaan layanan kesehatan } \\
\text { personal bagi lansia (WHO, 2007; WHO, 2015) }\end{array}$ \\
\hline
\end{tabular}

Sumber: WHO (2007), WHO (2015)

Oleh karena penelitian ini berfokus pada aksesibilitas fisik pada fasilitas puskesmas, maka dari hasil aksesibilitas fasilitas puskesmas ramah lansia dalam mendukung age friendly city yang meliputi aspek fisik (pada Tabel 2) didapatkan 2 variabel yaitu: 1) Jangkauan pelayanan sarana puskesmas bagi lansia, dan 2) Pelayanan sistem jaringan transportasi ramah lansia. Berikut variabel dan subvariabel dalam penelitian ini:

1. Variabel: Jangkauan Pelayanan Sarana Puskesmas bagi Lansia

Pelayanan kesehatan harus memiliki jarak yang dekat dengan permukiman atau tempat tinggal lansia (WHO, 2007). Subvariabel dalam variabel ini yakni:

- Jangkauan pelayanan sarana puskesmas

Adanya ketersediaan fasilitas pelayanan puskesmasnya bagi lansia (WHO, 2015). Lansia dapat mengakses pelayanan kesehatan salah satunya dipengaruhi oleh akses jarak terhadap sarana kesehatan (Sri S, dkk, 2019). Berdasarkan Budiman dan Cahyono (2017), dilihat dari jangkauan sarana puskesmas, lokasi asal tempat tinggal harus berada dalam radius pelayanan puskesmas yaitu 3000 meter dari sarana puskesmas.

2. Variabel: Pelayanan Sistem Jaringan Transportasi Ramah Lansia

WHO (2007) menyebutkan bahwa fasilitas pelayanan kesehatan harus memiliki lokasi yang aksesibel dengan interkoneksi sistem jaringan transportasi atau akses menuju lokasi puskesmas untuk lansia.

- Akses terhadap rute moda angkutan umum

Ketersediaan pelayanan angkutan umum merupakan salah satu elemen penting dalam mengidentifikasi aksesibilitas (WHO, 2007). Hal ini artinya puskesmas dapat dikatakan aksesibel oleh transportasi publik jika sarana puskesmas dilewati oleh rute angkutan umum. Semakin banyak alternatif rute yang melewati fasilitas publik maka semakin mudah fasilitas tersebut dicapai dengan angkutan umum (Buchika, dkk, 2019).

- Akses terhadap halte angkutan umum

Halte merupakan fasilitas untuk menaikkan dan menurunkan penumpang yang berada di sepanjang rute angkutan umum (Daud, 2005). Penyediaan halte bertujuan untuk menjamin keselamatan lansia dan memudahkan melakukan pergerakan menuju fasilitas tujuan (Lathifah dan Sadika, 2019). Oleh karena itu lansia diharapkan dapat merasakan nyaman untuk berjalan kaki dari halte untuk menuju sarana puskesmas atau sebaliknya. Apabila dalam menjangkau sarana, lansia tidak merasakan kelelahan, maka hal ini akan mendorong lansia untuk berkunjung ke lokasi tersebut (Massie, 2019). Hal ini dikarenakan apabila lansia tidak merasakan kelelahan dalam menjangkau lokasi sarana. Kenyamanan berjalan kaki bagi lansia dijelaskan Turel, dkk (2007) bahwa dalam melakukan perjalanan, lansia mampu berjalan dengan jarak maksimum 400 meter. Sehingga jarak yang ideal lansia untuk berjalan menuju fasilitas puskesmas dari halte yaitu maksimum 400 meter.

- Pelayanan jalur pejalan kaki ramah lansia

Secara fungsi, jalur pejalan kaki diperuntukkan khusus untuk pejalan kaki untuk memudahkan menghubungkan aktivitas menuju fasilitas publik (Dewi dan Saidah, 2017). Jalur khusus ini terpisah dari jalan dan letaknya bersebelahan di sepanjang jalan (Frans, dkk, 2016). Menurut Surat Edaran Menteri Pekerjaan Umum dan 
Perumahan Rakyat Nomor 2 Tahun 2018 tentang Pedoman Perencanaan Teknis Fasilitas Pejalan Kaki, jalur pejalan kaki berada pada kelas jalan arteri, jalan kolektor, dan jalan lokal. Bagi lansia, jalur pejalan kaki seharusnya dilengkapi dengan marka jalur (WHO, 2007). Marka jalur ini berdasarkan Peraturan Menteri Perhubungan Nomor 98 Tahun 2017 tentang Penyediaan Aksesibilitas pada Pelayanan Jasa Transportasi Publik bagi Pengguna Jasa Berkebutuhan Khusus dibuat sebagai guiding blocks atau ubin pemandu untuk menghubungkan jalan dengan sarana. Selain itu jalur pejalan kaki harus bebas dari hambatan yang berkaitan dengan segi keamanan bagi lansia agar dapat merasa aman (WHO, 2007). Hambatan dapat berupa adanya penyalahgunaan jalur pejalan kaki untuk parkir kendaraan atau digunakan PKL untuk berdagang (Sitanggang, dkk 2018).

- Ketersediaan ruang parkir prioritas bagi lansia

Peraturan Menteri Perhubungan Nomor 98 Tahun 2017 tentang Penyediaan Aksesibilitas pada Pelayanan Jasa Transportasi Publik bagi Pengguna Jasa Berkebutuhan Khusus menyebutkan bahwa aksesibilitas bagi lansia meliputi penyediaan tempat parkir yang dapat mudah diakses dengan ditandai petunjuk parkir untuk lansia

\section{METODE PENELITIAN}

Metode penelitian yang digunakan adalah pendekatan deskriptif, dengan teknik analisis skoring skala likert yang dilengkapi pemetaan pada software ArcGIS 10.2. Metode survei dalam penelitian ini yaitu observasi, kuesioner, dan studi dokumen.

\subsection{OPERASIONALISASI VARIABEL}

Penelitian ini memiliki 2 variabel dengan masing-masing subvariabelnya. Dalam mengukur subvariabel, digunakan parameter dan indikator yang menggunakan skor 3, 2, dan 1 untuk melihat skor aspek aksesibilitas pada masing-masing sarana puskesmas (lihat Tabel 3). Berikut merupakan variabel, subvariabel, dan parameter penelitian ini.

Tabel 3. Variabel, Subvariabel, dan Parameter Penelitian

\begin{tabular}{|c|c|c|c|c|c|}
\hline Variabel & Subvariabel & arameter & $\begin{array}{c}\text { (3) } \\
\text { Tinggi }\end{array}$ & $\begin{array}{l}\text { Indikator } \\
\text { (2) } \\
\text { Sedang }\end{array}$ & $\begin{array}{c}\text { (1) } \\
\text { Rendah }\end{array}$ \\
\hline \multirow{5}{*}{$\begin{array}{l}\text { Jangkauan } \\
\text { Pelayanan } \\
\text { Sarana } \\
\text { Puskesmas } \\
\text { bagi Lansia } \\
\text { Pelayanan } \\
\text { Sistem } \\
\text { Jaringan } \\
\text { Transportasi } \\
\text { Ramah } \\
\text { Lansia }\end{array}$} & $\begin{array}{l}\text { Jangkauan } \\
\text { pelayanan } \\
\text { sarana } \\
\text { puskesmas }\end{array}$ & $\begin{array}{l}\text { Wilayah lokasi lansia } \\
\text { terlayani oleh sarana } \\
\text { puskesmas dalam } \\
\text { radius } 3000 \text { meter dari } \\
\text { titik sarana puskesmas. }\end{array}$ & $\begin{array}{l}>66 \% \text { dari wilayah } \\
\text { kecamatan terlayani } \\
\text { oleh sarana puskesmas }\end{array}$ & $\begin{array}{l}33,3 \% \text { - } 66,6 \% \text { dari } \\
\text { wilayah kecamatan } \\
\text { terlayani oleh } \\
\text { sarana puskesmas }\end{array}$ & $\begin{array}{l}<33,3 \% \text { dari wilayah } \\
\text { kecamatan terlayani } \\
\text { oleh sarana } \\
\text { puskesmas }\end{array}$ \\
\hline & $\begin{array}{l}\text { Akses terhadap } \\
\text { rute moda } \\
\text { angkutan umum }\end{array}$ & $\begin{array}{l}\text { Sarana puskesmas } \\
\text { dilewati oleh rute } \\
\text { angkutan umum }\end{array}$ & $\begin{array}{l}\text { Sarana puskesmas } \\
\text { dilewati oleh lebih dari } 1 \\
\text { rute angkutan umum }\end{array}$ & $\begin{array}{l}\text { Sarana puskesmas } \\
\text { dilewati oleh } 1 \text { rute } \\
\text { angkutan umum }\end{array}$ & $\begin{array}{l}\text { Sarana puskesmas } \\
\text { tidak dilewati oleh rute } \\
\text { angkutan umum }\end{array}$ \\
\hline & $\begin{array}{l}\text { Akses terhadap } \\
\text { halte angkutan } \\
\text { umum }\end{array}$ & $\begin{array}{l}\text { Sarana puskesmas } \\
\text { memiliki jarak dengan } \\
\text { halte angkutan umum } \\
\text { maksimum } 400 \text { meter } \\
\text { dari titik lokasi sarna } \\
\text { puskesmas }\end{array}$ & $\begin{array}{l}\text { Sarana puskesmas } \\
\text { memiliki jarak } 0 \text { - } 400 \\
\text { meter terhadap halte }\end{array}$ & $\begin{array}{l}\text { Sarana puskesmas } \\
\text { memiliki jarak } 401 \text { - } \\
800 \text { meter terhadap } \\
\text { halte }\end{array}$ & $\begin{array}{l}\text { Sarana puskesmas } \\
\text { memiliki jarak }>800 \\
\text { meter terhadap halte }\end{array}$ \\
\hline & $\begin{array}{l}\text { Pelayanan jalur } \\
\text { pejalan kaki } \\
\text { ramah lansia }\end{array}$ & $\begin{array}{l}\text { Sarana puskesmas } \\
\text { terlayani oleh jalur } \\
\text { pejalan kaki ramah } \\
\text { lansia, dengan kriteria } \\
\text { tersedia marka jalur } \\
\text { dan bebas hambatan }\end{array}$ & $\begin{array}{l}\text { Sarana puskesmas } \\
\text { terlayani oleh jalur } \\
\text { pejalan kaki dengan } 2 \\
\text { kriteria }\end{array}$ & $\begin{array}{l}\text { Sarana puskesmas } \\
\text { terlayani oleh jalur } \\
\text { pejalan kaki dengan } \\
1 \text { kriteria }\end{array}$ & $\begin{array}{l}\text { Sarana puskesmas } \\
\text { tidak terlayani oleh } \\
\text { jalur pejalan kaki yang } \\
\text { memenuhi kriteria/ } \\
\text { tidak terlayani jalur } \\
\text { pejalan kaki }\end{array}$ \\
\hline & \begin{tabular}{lr}
\multicolumn{2}{l}{ Ketersediaan } \\
ruang & parkir \\
prioritas & bagi \\
lansia &
\end{tabular} & $\begin{array}{l}\text { Sarana puskesmas } \\
\text { tersedia ruang parkir } \\
\text { prioritas bagi lansia }\end{array}$ & $\begin{array}{l}\text { Sarana puskesmas } \\
\text { tersedia ruang parkir } \\
\text { prioritas bagi lansia }\end{array}$ & $\begin{array}{l}\text { Sarana puskesmas } \\
\text { tidak tersedia ruang } \\
\text { parkir prioritas bagi } \\
\text { lansia }\end{array}$ & $\begin{array}{l}\text { Sarana puskesmas } \\
\text { tidak tersedia ruang } \\
\text { parkir }\end{array}$ \\
\hline
\end{tabular}

Sumber: WHO (2007), WHO (2015), Budiman dan Cahyono (2017), Buchika, dkk (2019), Turel, dkk (2007), Sitanggang, dkk (2018), Peraturan Menteri Perhubungan Nomor 98 Tahun 2017 


\subsection{POPULASI DAN SAMPEL}

Wilayah studi penelitian yaitu Kota Yogyakarta dengan 18 sarana puskesmas. Teknik pengumpulan data dalam penelitian ini yakni observasi, kuesioner, dan studi dokumen. Studi dokumen dilakukan untuk mendapatkan data lokasi sarana puskesmas, jaringan jalan, rute angkutan umum, dan lokasi halte. Observasi dilakukan untuk mendapatkan data kondisi pelayanan jalur pejalan kaki dan ketersediaan ruang parkir prioritas bagi lansia. Hal ini tidak menggunakan teknik sampel yang artinya semua populasi sarana puskesmas menjadi sampel yang diteliti. Untuk jalur pejalan kaki akan dilakukan pada jaringan jalan yang melayani sarana puskesmas yaitu dalam radius 400 meter dari titik lokasi sarana puskesmas. Sedangkan pengumpulan data dengan kuesioner memiliki responden yaitu lansia (usia di atas 60 tahun) yang berkunjung ke puskesmas di Kota Yogyakarta. Menurut Laporan Profil Kesehatan Tahun 2019 Kota Yogyakarta, jumlah lansia yang mendapatkan pelayanan kesehatan puskesmas di Kota Yogyakarta berjumlah 20.103 jiwa. Jumlah sampel responden untuk pengambilan data pada penelitian ini adalah 100 responden yang tersebar di setiap puskesmas dengan sistem membagikan kuesioner untuk ditanyakan langsung kepada responden yang ditemui.

\subsection{TEKNIK ANALISIS}

\subsubsection{Analisis Skoring}

Pelayanan fasilitas puskesmas yang ramah lansia mengedepankan equity (kesetaraan) (WHO, 2015). Oleh karena itu, jumlah fasilitas puskesmas yang ramah lansia harus lebih besar daripada puskesmas yang tidak ramah bagi lansia. Dalam konteks aksesibilitas, jumlah fasilitas puskesmas yang ramah lansia ini dapat diukur untuk skoring tingkat aksesibilitasnya. Pertama, dilakukan skoring untuk masing-masing subvariabelnya pada keseluruhan puskesmas di Kota Yogyakarta menggunakan tiga skala penilaian. Jumlah puskesmas yang memenuhi kriteria akan dikonversi menjadi persentase. Keseluruhan total sampel 18 puskesmas maka nilai tertinggi yang didapatkan yaitu 100\% (18 puskesmas), sedangkan nilai terendah yang didapatkan yaitu $0 \%$ (0 puskesmas). Kemudian dibagi ke dalam 3 kelas, dengan rumus perhitungan interval sebagai berikut.

$$
\text { Interval }=\text { Nilai maksimum }- \text { Nilai minimum } / \text { Jumlah kelas }=100 \%-0 \% / 3=33,3 \%
$$

Sehingga jika yang memenuhi ada $66,7 \%$ - 100\% dari total puskesmas, maka skor subvariabel, yaitu tinggi (3). Sedangkan jika yang memenuhi ada 33,4\% - 66,6\% dari total puskesmas, maka skor subvariabel sedang (2). Jika yang memenuhi hanya $0 \%-33,3 \%$ dari total puskesmas maka skor subvariabel rendah (1). Kemudian tahap kedua, setelah mengetahui nilai pada setiap subvariabel, maka dapat diketahui nilai pada masing-masing variabelnya. Dengan hasil perhitungan interval, berikut pembobotan untuk analisis pada setiap variabel dengan teknik skoring (Tabel 5).

Tabel 5. Skala Penilaian dari Setiap Variabel

\begin{tabular}{|c|c|c|c|c|c|}
\hline Variabel & Subvariabel & Interval & $\begin{array}{c}(3) \\
\text { Tinggi }\end{array}$ & $\begin{array}{l}\text { kala Penilaian } \\
\text { (2) } \\
\text { Sedang }\end{array}$ & $\begin{array}{c}\text { (1) } \\
\text { Rendah }\end{array}$ \\
\hline $\begin{array}{l}\text { Jangkauan pelayanan } \\
\text { sarana puskesmas bagi } \\
\text { lansia }\end{array}$ & $\begin{array}{l}\text { Jangkauan pelayanan sarana puskesmas } \\
\text { (1) }\end{array}$ & 1 & $\begin{array}{l}\text { Jika total } \\
\text { skor } \\
\text { variabel } \\
\text { adalah } 3\end{array}$ & $\begin{array}{l}\text { Jika total } \\
\text { skor } \\
\text { variabel } \\
\text { adalah } 2\end{array}$ & $\begin{array}{l}\text { Jika total } \\
\text { skor } \\
\text { variabel } \\
\text { adalah } 1\end{array}$ \\
\hline 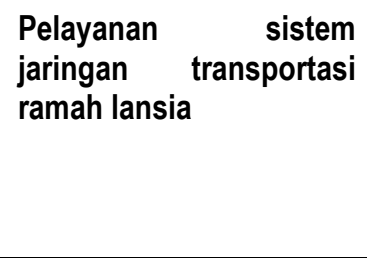 & $\begin{array}{l}\text { - Akses terhadap rute angkutan umum } \\
\text { - Akses terhadap halte angkutan umum } \\
\text { - Pelayanan jalur pejalan kaki ramah lansia } \\
\text { - Ketersediaan ruang parkir prioritas bagi } \\
\text { lansia } \\
\begin{array}{ll}\text { (4) }\end{array}\end{array}$ & 2,66 & $\begin{array}{l}\text { Jika total } \\
\text { skor } \\
\text { variabel } \\
\text { adalah } \\
9,34-12\end{array}$ & $\begin{array}{l}\text { Jika total } \\
\text { skor } \\
\text { variabel } \\
\text { adalah } \\
6,67-9,33\end{array}$ & $\begin{array}{l}\text { Jika total } \\
\text { skor } \\
\text { variabel } \\
\text { adalah } \\
4-6,66\end{array}$ \\
\hline
\end{tabular}

Setelah itu, jumlah dari keseluruhan variabel tersebut guna mengetahui aksesibilitas fisik pada fasilitas puskesmas ramah lansia dalam mendukung konsep Age Friendly City di Kota Yogyakarta. Aksesibilitas tersebut juga terbagi menjadi kategori tinggi, sedang, dan rendah. Dengan nilai maksimalnya adalah 6 dari hasil perkalian skor tertinggi (3) dengan jumlah variabel (2), sedangkan nilai minimalnya adalah 2 yang didapatkan dari hasil perkalian skor terendah (1) dengan jumlah variabel (2). 
Sehingga nilai intervalnya yakni 1,33 . Jadi, nilai aksesibilitas fisik pada fasilitas puskesmas ramah lansia dalam mendukung konsep age friendly city di Kota Yogyakarta, yaitu:

- Jika nilai hasil skoring di antara 4,68 - 6, maka aksesibilitas fisik pada fasilitas puskesmas ramah lansia dalam mendukung konsep Age Friendly City di Kota Yogyakarta termasuk kategori tinggi.

- Jika nilai hasil skoring di antara 3,34 - 4,67, maka aksesibilitas fisik pada fasilitas puskesmas ramah lansia dalam mendukung konsep Age Friendly City di Kota Yogyakarta termasuk kategori sedang.

- Jika nilai hasil skoring di antara 2-3,33, maka aksesibilitas fisik pada fasilitas puskesmas ramah lansia dalam mendukung konsep Age Friendly City di Kota Yogyakarta termasuk kategori rendah.

\section{HASIL DAN PEMBAHASAN}

\subsection{JANGKAUAN PELAYANAN SARANA PUSKESMAS BAGI LANSIA}

Berdasarkan parameter penelitian jangkauan pelayanan sarana puskesmas bagi lansia dapat dilihat dengan proporsi wilayah yang terlayani oleh sarana puskesmas (radius 3000 meter dari titik sarana puskesmas). Dari hasil kuesioner, lansia yang menggunakan layanan sarana puskesmas merupakan penduduk lansia yang berdomisili di wilayah Kota Yogyakarta. Hasil analisis menyatakan bahwa setiap wilayah kecamatan telah terlayani oleh sarana puskesmas di kecamatan tersebut. Oleh karena itu, proporsi wilayah yang berada di dalam jangkauan pelayanan ideal puskesmas (3000 meter) adalah 14 kecamatan atau 100\% terhadap wilayah keseluruhan Kota Yogyakarta. Hal ini menjelaskan bahwa jangkauan pelayanan sarana puskesmas telah merata bagi lansia di Kota Yogyakarta (lihat Gambar 1, area berwarna kuning adalah area jangkauan puskesmas). Sehingga, jangkauan sarana puskesmas bagi lansia dinilai tinggi dan memiliki skor 3.

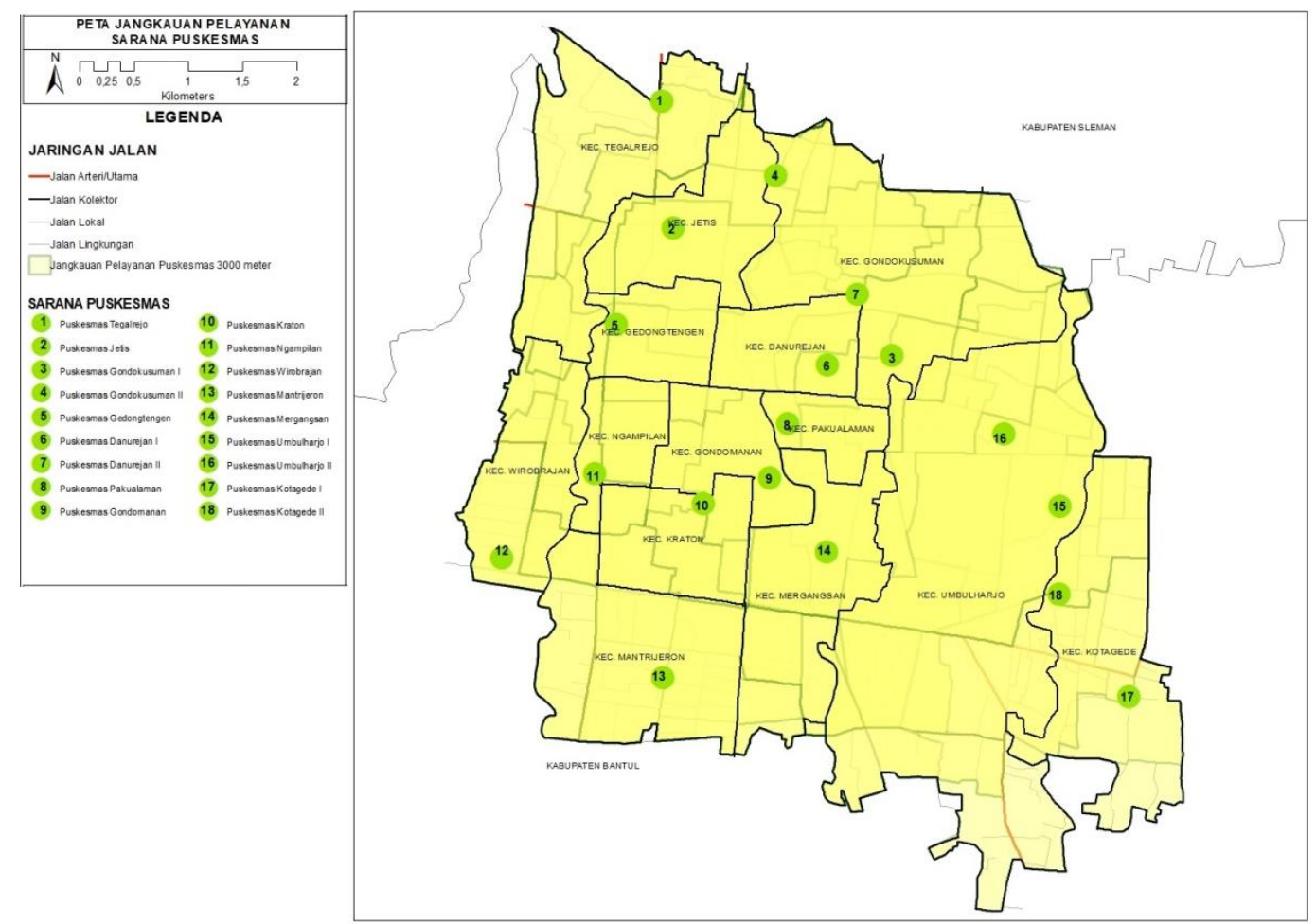

Gambar 1. Peta Jangkauan Pelayanan Sarana Puskesmas bagi Lansia

Baik WHO (2007) dan WHO (2015) keduanya membahas pentingnya distribusi ketersediaan pelayanan puskesmas yang dapat mempengaruhi aksesibilitas fasilitas puskesmas bagi lansia. Kota Yogyakarta memperhatikan kebutuhan lansia dari segi penyediaan sarana puskesmas bagi lansia. Sarana puskesmas dengan pelayanan poli lansianya telah tersedia dan terdistribusi di setiap kecamatan di Kota Yogyakarta. Lansia yang berkunjung ke sarana puskesmas pun adalah lansia yang tempat tinggalnya berada di kecamatan dimana lokasi puskesmas tersebut memiliki jarak tidak lebih dari 3000 meter. Jarak 
tersebut menurut Budiman dan Cahyono (2017) masih berada dalam wilayah pelayanan sarana puskesmas. Sehingga puskesmas dapat lebih mudah dijangkau dari tempat tinggal lansia. Dengan seluruh wilayah kecamatan di Kota Yogyakarta yang telah terlayani oleh semua sarana puskesmas yang ada (jangkauan pelayanan sarana puskesmas bagi lansia tinggi), seperti yang dikatakan oleh WHO (2015) menandakan bahwa tidak ada kesenjangan pada ketersediaan pelayanan puskesmas bagi lansia. Oleh karena itu, dengan kondisi jangkauan pelayanan sarana puskesmas di Kota Yogyakarta tersebut, maka dapat memberikan dampak yang positif untuk mengoptimalkan aksesibilitas fasilitas puskesmas bagi lansia di Kota Yogyakarta.

\subsection{PELAYANAN SISTEM JARINGAN TRANSPORTASI RAMAH LANSIA}

\subsubsection{Akses Terhadap Rute Angkutan Umum}

Bus Trans Jogja memiliki rute pelayanan yang beroperasi di Kota Yogyakarta. Namun meski Kota Yogyakarta telah tersedia pelayanan angkutan umum yaitu Bus Trans Jogja, jaringan rute yang ada belum mampu melayani keseluruhan sarana puskesmas yang ada. Hal ini diikarenakan Bus Trans Jogja melewati jalan utama yaitu jalan arteri dan kolektor, sedangkan masih ada sarana puskesmas yang lokasinya tidak berada pada jalan arteri ataupun kolektor yang dilewati oleh angkutan umum. Artinya akses sarana puskesmas terhadap rute angkutan umum belum merata di seluruh sarana puskesmas di Kota Yogyakarta (lihat Gambar 2).

Berdasarkan parameter sarana puskesmas yang harus dilewati oleh lebih dari 1 rute angkutan umum, hanya ada 7 sarana puskesmas (38,8\% dari total sarana puskesmas) yang memenuhi parameter tersebut yaitu Puskesmas Tegalrejo, Puskesmas Jetis, Puskesmas Gondokususman II, Puskesmas Gedongtengen, Puskesmas Danurejan II, Puskesmas Ngampilan, dan Puskesmas Kotagede I (lihat Gambar 2). Oleh karenanya, skor untuk akses terhadap rute angkutan umum yaitu 2 dan termasuk dalam kategori sedang.

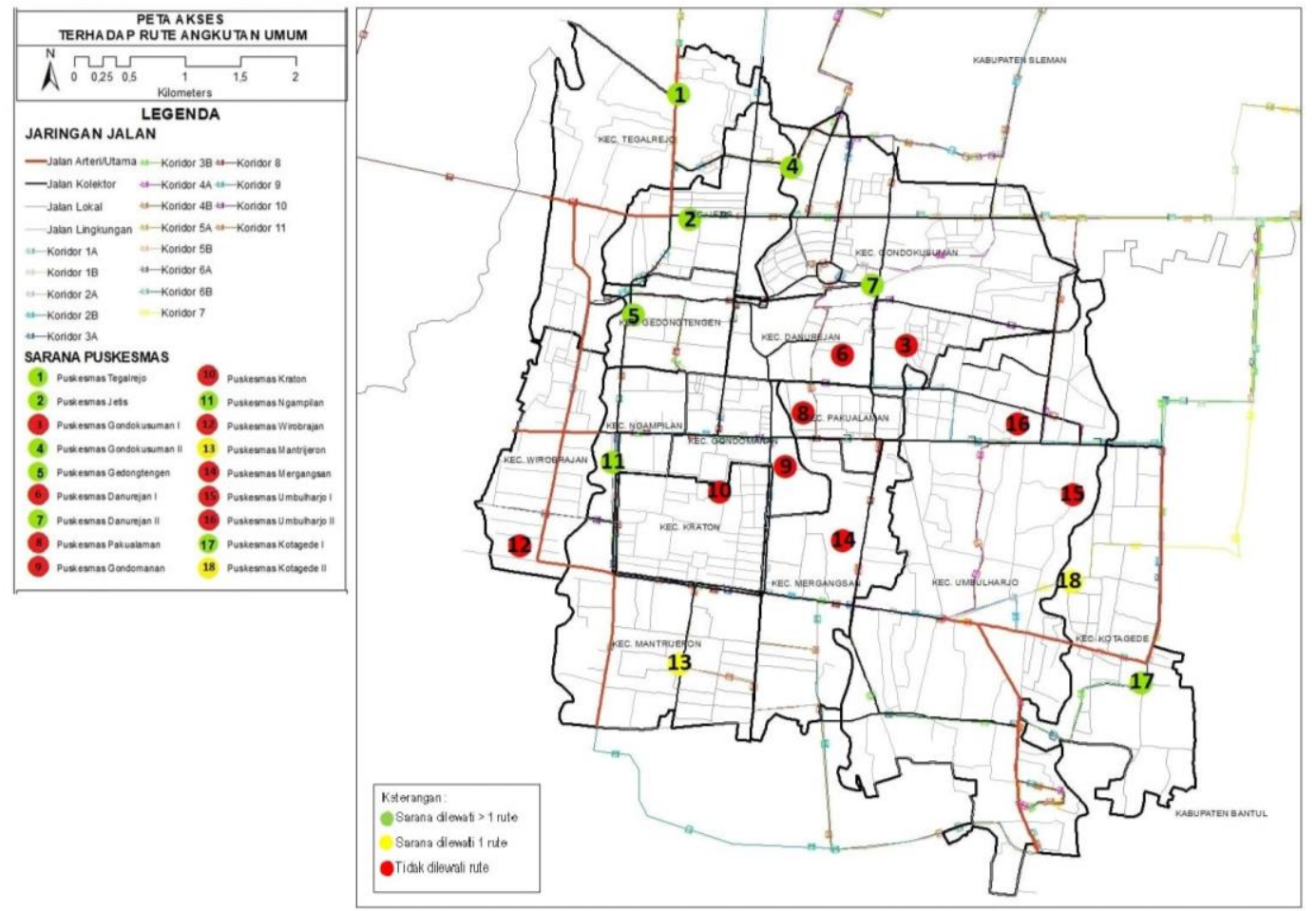

Gambar 2. Peta Akses terhadap Rute Angkutan Umum

Pendapat dari WHO (2007) lokasi fasilitas puskesmas aksesibel apabila dilayani oleh transportasi umum. Kemudahan dalam mencapai lokasi puskesmas ini dapat dilihat berdasarkan adanya interkoneksi sarana puskesmas dengan rute angkutan umum (WHO, 2015). Di Kota Yogyakarta tidak semua sarana puskesmas aksesibel dengan Bus Trans Jogja. Kondisi akses sarana puskesmas di Kota Yogyakarta terhadap rute dapat dikatakan semakin sulit untuk dicapai berdasarkan teori dari 
Buchika, dkk (2019) dikarenakan tidak adanya rute alternatif untuk mencapai puskesmas tersebut. Dengan banyaknya sarana puskesmas yang tidak ramah lansia karena tidak ada akses terhadap rute angkutan umum ini, maka menurut WHO (2015) hal ini dapat memicu kesenjangan dalam kemudahan mencapai puskesmas bagi lansia di Kota Yogyakarta. Kondisi semacam ini dapat mengakibatkan kurang optimalnya aksesibilitas fasilitas puskesmas bagi lansia dalam memanfaatkan pelayanan puskesmas karena terhambat tidak adanya akses terhadap rute angkutan umum menuju ke lokasi sarana puskesmas. Sehingga apabila lansia ingin menggunakan layanan angkutan umum, lansia harus berjalan kaki untuk mencari jalan yang dilalui oleh angkutan umum

\subsubsection{Akses Terhadap Halte Angkutan Umum}

Dilihat dari persebarannya, halte angkutan umum di Kota Yogyakarta memiliki sebaran yang belum merata di setiap kelas jalan, karena sebagian besar lokasi halte yang juga mengikuti keberadaan rute Bus Trans Jogja yaitu berada di kelas jalan arteri dan jalan kolektor. Sarana puskesmas di Kota Yogyakarta yang memiliki jarak yang jauh dengan halte (lebih dari 400 meter) adalah puskesmas yang lokasinya berada di jalan yang tidak dilewati oleh rute angkutan umum atau berada di jalan lokal atau jalan lingkungan. Jauhnya jarak akses halte ini akan menyebabkan lansia mengalami kesulitan dalam menggunakan layanan angkutan umum menuju lokasi sarana puskesmas. Lansia yang ingin menuju ke puskesmas harus berjalan lebih jauh dari lokasi halte dan dapat memicu kelelahan dan ketidaknyamanan.

Berdasarkan parameter penelitian sarana puskesmas harus memiliki akses terhadap halte angkutan umum dalam jarak maksimum 400 meter dari titik lokasi sarana puskesmas. Namun hanya ada 3 sarana puskesmas $(16,7 \%$ dari total sarana puskesmas) yang memiliki jarak di antara 0 hingga 400 meter untuk akses terhadap halte angkutan umumnya yaitu Puskesmas Jetis (Halte Diponegoro), Puskesmas Gondomanan (Halte Katamso 2), dan Puskesmas Kotagede I (Halte Gedongkuning Departemen Kehutanan) (lihat Gambar 3). Maka skor akses terhadap halte angkutan umum yaitu 1 dan termasuk dalam kategori rendah.

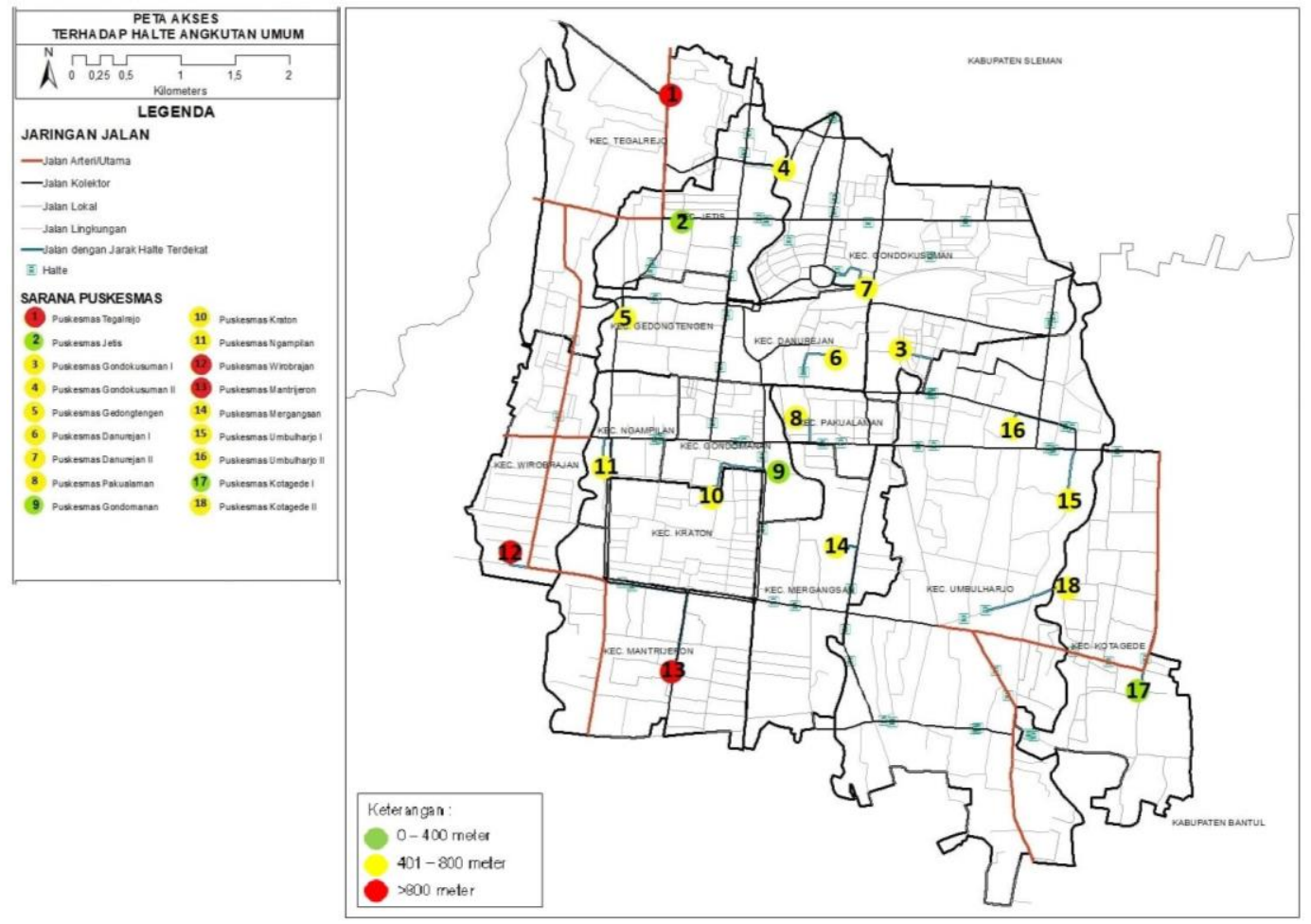

Gambar 3. Peta Akses terhadap Halte Angkutan Umum

WHO (2007) dan WHO (2015) berpendapat bahwa lokasi fasilitas puskesmas aksesibel apabila memiliki akses terhadap halte angkutan umum. Meskipun sarana puskesmas dilewati oleh rute angkutan umum, belum tentu pada puskesmas tersebut memiliki akses terhadap halte angkutan umum apabila ditinjau dari jaraknya. Keberadaan halte yang jaraknya dengan sarana 
puskesmas di Kota Yogyakarta yang tidak sesuai dengan jarak maksimum lansia berjalan yang ideal seperti dijelaskan oleh Turel, dkk (2007) yaitu 400 meter, maka akan menjadi salah satu pemicu hambatan bagi lansia yang akan berjalan menuju puskesmas dari halte. Pada Kota Yogyakarta, lebih banyak sarana puskesmas yang akses terhadap haltenya tidak sesuai dengan kriteria yang menandakan bahwa dinilai dari teori WHO (2015) terdapat kesenjangan pelayanan puskesmas bagi lansia dalam mengakses lokasinya. Dukungan akses terhadap halte angkutan umum yang rendah menyebabkan aksesibilitas fasilitas puskesmas bagi lansia menjadi rendah pula. Halte angkutan umum yang seharusnya menjadi salah satu pendukung aksesibilitas fasilitas puskesmas, akan tetapi masih belum memperhatikan keterbatasan kemampuan lansia dalam melakukan aktivitas terutama dalam menempuh jaraknya menuju puskesmas dengan berjalan kaki (WHO, 2007).

\subsubsection{Pelayanan Jalur Pejalan Kaki Ramah Lansia}

Berdasarkan hasil observasi, kualitas pelayanan jalur pejalan kaki pada puskesmas di Kota Yogyakarta yang ramah bagi lansia masih minim dilihat dari jalur pejalan kaki yang ada belum dilengkapi dengan marka jalur pejalan kaki di kedua sisi jalannya (Gambar 4). Selain itu, adanya penyimpangan penggunaan fungsi jalur pejalan kaki seperti untuk aktivitas PKL bahkan digunakan sebagai area parkir kendaraan (Gambar 5 dan Gambar 6). Hal ini dapat mengganggu lansia yang akan berjalan melewati jalur pejalan kaki tersebut.

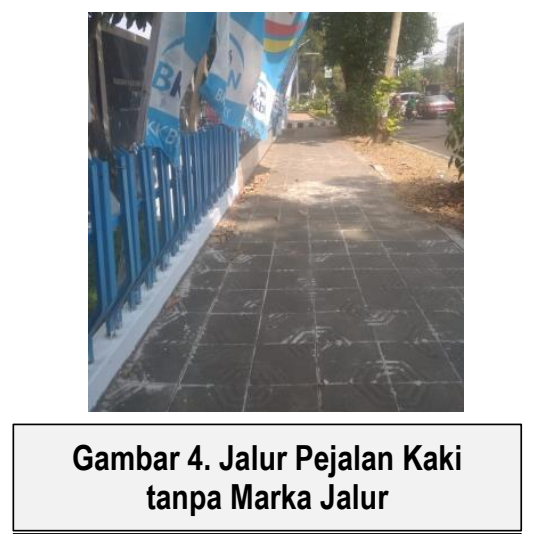

Kondisi jalur pejalan kaki tidak dilengkapi dengan marka jalur yang dapat menyebabkan disorientasi arah bagi lansia yang sedang berjalan.

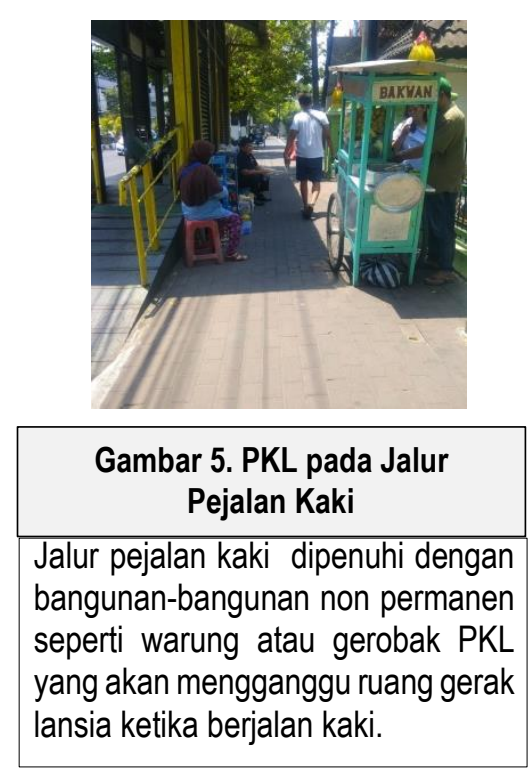

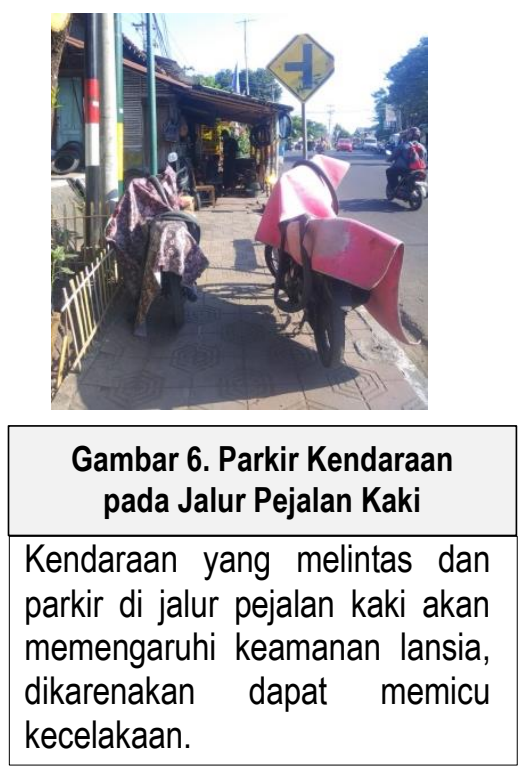

Dilihat dari parameternya sarana puskesmas harus terlayani oleh jalur pejalan kaki ramah lansia yang memenuhi kriteria (tersedia marka jalur pejalan kaki dan bebas hambatan). Pada Gambar 7 menunjukkan tidak ada sarana puskesmas di Kota Yogyakarta yang memenuhi kriteria pelayanan jalur pejalan kaki ramah lansia ( $0 \%$ dari total sarana puskesmas). Maka dari itu, pelayanan jalur pejalan kaki pada fasilitas puskesmas di Kota Yogyakarta termasuk dalam kategori rendah dengan skor 1.

WHO (2007) dan Peraturan Peraturan Menteri Perhubungan Nomor 98 Tahun 2017 tentang Penyediaan Aksesibilitas pada Pelayanan Jasa Transportasi Publik bagi Pengguna Jasa Berkebutuhan Khusus menjelaskan jalur pejalan kaki untuk lansia seharusnya dilengkapi dengan marka jalur yang berfungsi sebagai ubin pemandu atau guiding block untuk menghubungkan jalan dengan sarana. Apabila dilihat dari kondisi pelayanan jalur pejalan kaki pada sarana puskesmas di Kota Yogyakarta yang rendah dari segi ketersediaan marka jalurnya, hal ini mengakibatkan disorientasi arah bagi lansia karena kurang maksimalnya fungsi jalur pejalan kaki untuk memandu lansia untuk berjalan menuju puskesmas. Selain itu, banyaknya hambatan jalur pejalan kaki seperti keberadaan PKL dan sebagai area parkir kendaraan akan membuat ruang gerak lansia menjadi lebih sempit dan memungkinkan adanya resiko jatuh atau kecelakaan. Hal ini akan memicu ketidaknyamanan dalam berjalan kaki seperti dalam teori Sitanggang, dkk (2018). Rendahnya kualitas pelayanan jalur pejalan kaki yang ramah lansia pada sarana puskesmas, menandakan Kota Yogyakarta masih memiliki kendala dalam menciptakan ruang yang aman dan nyaman bagi lansia dalam mengakses lokasi puskesmas dengan fasilitas jalur pejalan kaki. 
Desa-Kota, Vol. 3, No. 1, 2021, 1-16

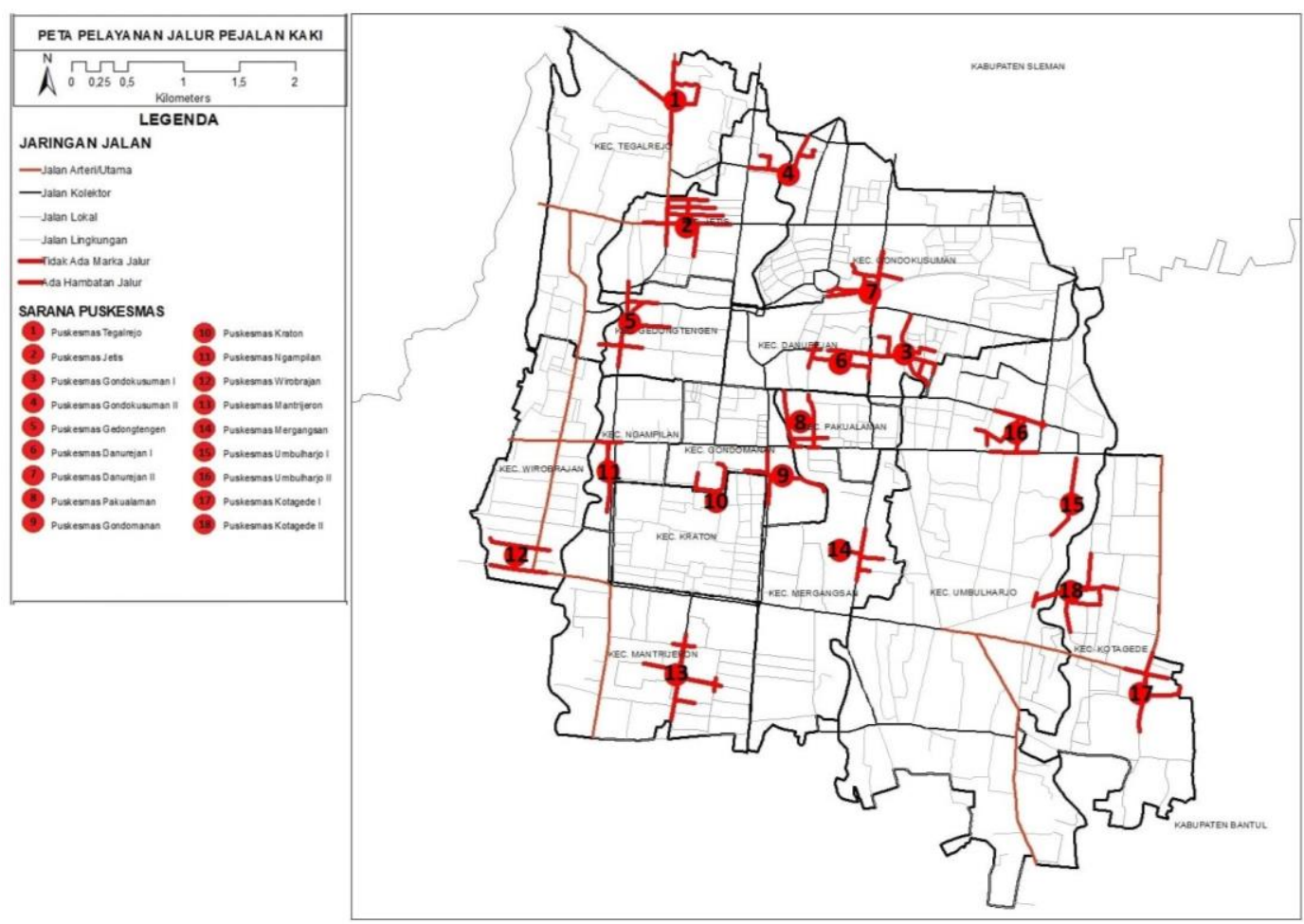

Gambar 7. Peta Pelayanan Jalur Pejalan Kaki Ramah Lansia

\subsubsection{Ketersediaan Ruang Parkir Prioritas Bagi Lansia}

Berdasarkan parameter penelitian, sarana puskesmas haruslah tersedia ruang parkir prioritas bagi lansia. Hasil observasi ruang parkir di setiap sarana puskesmas di Kota Yogyakarta telah dimiliki namun hanyalah ruang parkir untuk umum atau tidak ada area yang diprioritaskan secara khusus untuk parkir lansia (lihat Gambar 8). Hal ini menunjukkan bahwa tidak ada sarana puskesmas ( $0 \%$ dari total sarana puskesmas) di Kota Yogyakarta yang memenuhi parameter sehingga membuat ketersediaan ruang parkir prioritas bagi lansia memiliki skor 1 yang masuk dalam kategori rendah.

Menurut WHO (2007) dan WHO (2015) dengan adanya ruang parkir prioritas bagi lansia memberikan dampak yang positif untuk aksesibilitas bangunan puskesmas untuk lansia. Ruang parkir yang diprioritaskan khusus bagi lansia ini juga penting menurut Peraturan Menteri Perhubungan Nomor 98 Tahun 2017 tentang Penyediaan Aksesibilitas pada Pelayanan Jasa Transportasi Publik bagi Pengguna Jasa Berkebutuhan Khusus agar area pelayanan dapat mudah diakses. Namun hal ini berbanding terbalik dengan kondisi ketersediaan ruang parkir prioritas bagi lansia pada sarana puskesmas di Kota Yogyakarta yang dinilai rendah. Oleh karena itu dapat memicu rendahnya aksesibilitas fisik fasilitas puskesmas bagi lansia. Hal ini dikarenakan kurang amannya lansia yang berkunjung ke puskesmas untuk memarkirkan kendaraannya dengan nyaman, tanpa terhalangi ataupun terganggu kendaraan pengunjung umum lainnya. Bahkan jika terdapat lansia yang menggunakan kursi roda, akan lebih mudah untuk menaikkan dan menurunkannya dari kendaraan. 


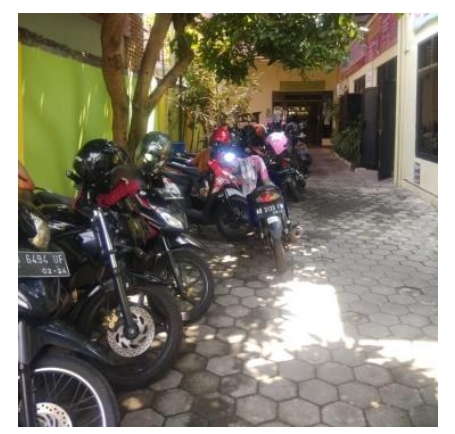

Gambar 8. Kondisi Ruang Parkir Puskesmas

\subsection{AKSESIBILITAS FISIK PADA FASILITAS PUSKESMAS RAMAH LANSIA DALAM MENDUKUNG KONSEP AGE FRIENDLY CITY}

Berdasarkan analisis data, maka dapat disimpulkan bahwa aksesibilitas fasilitas puskesmas ramah lansia dalam mendukung age friendly city di Kota Yogyakarta adalah dengan hasil analisis seperti pada Tabel 5 dengan puskesmas yang telah diurutkan dari puskesmas yang memiliki kondisi atau hasil penilaian tertinggi hingga puskesmas yang memiliki hasil penilaian terendah dengan kondisi variabel rendah terbanyak

Tabel 5. Resume Hasil Analisis Aksesibilitas Fisik pada Fasilitas Puskesmas Ramah Lansia dalam Mendukung Konsep Age Friendly City di Kota Yogyakarta

\begin{tabular}{|c|c|c|c|c|c|c|}
\hline \multirow[b]{2}{*}{ No } & \multirow[b]{2}{*}{ Puskesmas } & \multicolumn{5}{|c|}{ Kondisi } \\
\hline & & $\begin{array}{l}\text { Pelayanan } \\
\text { Puskesmas } \\
\text { bagi Lansia }\end{array}$ & $\begin{array}{l}\text { Akses terhadap } \\
\text { rute angkutan } \\
\text { umum }\end{array}$ & $\begin{array}{l}\text { Akses terhadap } \\
\text { halte angkutan } \\
\text { umum }\end{array}$ & $\begin{array}{l}\text { Pelayanan jalur } \\
\text { pejalan kaki } \\
\text { ramah lansia }\end{array}$ & $\begin{array}{c}\text { Ketersediaan } \\
\text { ruang parkir } \\
\text { prioritas lansia }\end{array}$ \\
\hline 1 & Jetis & Tinggi & Tingqi & Tinggi & Rendah & Rendah \\
\hline 2 & Kotagede 1 & Tinggi & Tinggi & Tinggi & Rendah & Rendah \\
\hline 3 & Gondokusuman 2 & Tinggi & Tinggi & Sedang & Rendah & Rendah \\
\hline 4 & Gedongtengen & Tinggi & Tinggi & Sedang & Rendah & Rendah \\
\hline 5 & Danurejan 2 & Tinggi & Tinggi & Sedang & Rendah & Rendah \\
\hline 6 & Ngampilan & Tinggi & Tinggi & Sedang & Rendah & Rendah \\
\hline 7 & Tegalrejo & Tinggi & Tinggi & Rendah & Rendah & Rendah \\
\hline 8 & Gondomanan & Tinggi & Rendah & Tinggi & Rendah & Rendah \\
\hline 9 & Kotagede 2 & Tinggi & Sedang & Sedang & Rendah & Rendah \\
\hline 10 & Gondokusuman 1 & Tinggi & Rendah & Sedang & Rendah & Rendah \\
\hline 11 & Danurejan 1 & Tinggi & Rendah & Sedang & Rendah & Rendah \\
\hline 12 & Pakualaman & Tinggi & Rendah & Sedang & Rendah & Rendah \\
\hline 13 & Kraton & Tinggi & Rendah & Sedang & Rendah & Rendah \\
\hline 14 & Mantrijeron & Tinggi & Sedang & Rendah & Rendah & Rendah \\
\hline 15 & Mergangsan & Tinggi & Rendah & Sedang & Rendah & Rendah \\
\hline 16 & Umbulharjo 1 & Tinggi & Rendah & Sedang & Rendah & Rendah \\
\hline 17 & Umbulharjo 2 & Tinggi & Rendah & Sedang & Rendah & Rendah \\
\hline & Wirobrajan & Tinggi & Rendah & Rendah & Rendah & Rendah \\
\hline \multirow{2}{*}{\multicolumn{2}{|c|}{$\begin{array}{l}\text { Persentase jumlah } \\
\text { puskesmas memenuhi } \\
\text { parameter } \\
\text { Keterangan (Skor Variabel) } \\
\text { Skor Total Variabel }\end{array}$}} & $\begin{array}{c}100 \% \text { dari total } \\
\text { puskesmas } \\
\text { (3) }\end{array}$ & $\begin{array}{l}38,8 \% \text { dari total } \\
\text { puskesmas } \\
\text { (2) }\end{array}$ & $\begin{array}{l}16,7 \% \text { dari total } \\
\text { puskesmas } \\
\text { (1) }\end{array}$ & $\begin{array}{l}0 \% \text { dari total } \\
\text { puskesmas } \\
\text { (1) }\end{array}$ & $\begin{array}{l}0 \% \text { dari total } \\
\text { puskesmas } \\
\text { (1) }\end{array}$ \\
\hline & & Tinggi (3) & \multicolumn{4}{|c|}{ Rendah (1) } \\
\hline \multicolumn{7}{|c|}{ Kategori: 4 / 6 skor total variabel : SEDANG } \\
\hline
\end{tabular}


Berdasarkan Tabel 5 dapat diketahui bahwa puskesmas di Kota Yogyakarta memiliki kondisi atau hasil penilaian yang bermacam-macam. Dari keseluruhan puskesmas di Kota Yogyakarta, puskesmas yang kondisi atau hasil penilaiannya menduduki posisi pertama adalah Puskesmas Jetis walaupun tidak semua variabel terkategori tinggi dikarenakan kondisi pelayanan jalur pejalan kaki ramah lansia dan ketersediaan ruang parkir prioritas yang rendah. Sedangkan puskesmas yang kondisi atau hasil penilaiannya menduduki posisi terakhir adalah Puskesmas Wirobrajan karena memiliki paling banyak kondisi terkategori rendah pada variabelnya.

Hasil pada setiap aspek menunjukkan skor dari aksesibilitas fisik pada fasilitas puskesmas ramah lansia dalam mendukung konsep age friendly city di Kota Yogyakarta adalah 4 dari skor total 6 (lihat pada Tabel 5), sehingga dapat diinterpretasikan bahwa aksesibilitas fisik pada fasilitas puskesmas ramah lansia dinilai sedang dalam mendukung konsep Age Friendly City di Kota Yogyakarta. Aspek yang paling mendukung yaitu jangkauan pelayanan sarana puskesmas bagi lansia, dikarenakan Kota Yogyakarta telah terdistribusi sarana puskesmas yang dapat menjangkau tempat tinggal lansia. Meskipun aspek jangkauan sarana puseksmas bagi lansia tergolong tinggi dalam mendukung konsep Age Friendly City di Kota Yogyakarta, namun aspek pelayanan sistem jaringan transportasi ramah lansia masih dikategorikan rendah. Hal ini dikarenakan masih ada kondisi komponen aksesibilitas puskesmas yang berada dalam kategori sedang hingga rendah, seperti sarana puskesmas yang belum memiliki rute angkutan umum lebih dari 1 rute bahkan tidak ada akses terhadap rute angkutan umum. Sedangkan dilihat dari segi akses terhadap halte angkutan umum, bagi lansia lokasi puskesmas masih sulit untuk diakses dari halte karena masih banyak puskesmas yang jaraknya dengan halte lebih dari 400 meter atau tidak memenuhi jarak ideal lansia berjalan kaki. Komponen aspek pelayanan sistem jaringan transportasi yang lainnya dari segi pelayanan jalur pejalan kaki, sarana puskesmas di Kota Yogyakarta masih sulit untuk diakses lansia yang ingin berjalan kaki menuju lokasinya, disebabkan karena jalur pejalan kaki yang ada tidak dilengkapi marka jalur dan banyak hambatan jalur sehingga mengganggu keamanan dan kenyamanan lansia. Serta puskesmas di Kota Yogykarta tidak ada yang menyediakan ruang parkir prioritas bagi lansia untuk kebutuhan aksesibilitas bangunan sarana puskesmas.

Oleh karena itu, rekomendasi penelitian untuk memperbaiki kualitas pelayanan asilitas puskesmas bagi lansia di Kota Yogyakarta yaitu perlunya perbaikan akses pelayanan rute angkutan umum pada fasilitas puskesmas, letak lokasi halte, perbaikan kondisi jalur pejalan kaki dengan adanya penambahan marka jalur, penertiban PKL dan parkir kendaraan yang ada pada jalur pejalan kaki, serta menyediakan ruang parkir prioritas pada setiap sarana puskesmas. Dengan memenuhi persyaratan tersebut, penerapan age friendly city di Kota Yogyakarta.dapat berjalan dengan adanya kualitas aksesibilitas fisik fasilitas puskesmas ramah lansia yang mendukung.

\section{KESIMPULAN}

Dalam mendukung konsep Age Friendly City, aksesibilitas fisik fasilitas puskesmas dapat dilihat dari jangkauan pelayanan puskesmas bagi lansia dan pelayanan sistem jaringan transportasi ramah lansia. Pada Kota Yogyakarta sendiri, sarana puskesmas telah tersedia dan dapat menjangkau lansia di setiap wilayah kecamatannya. Namun untuk mengakses lokasinya masih perlu didukung dengan pelayanan sistem jaringan transportasi yang ramah lansia dikarenakan rute angkutan umum belum mampu melayani secara merata sarana puskesmas yang ada di Kota Yogyakarta, akses terhadap halte angkutan umum yang jaraknya tidak memberikan kenyamanan bagi lansia yang berjalan kaki dari halte menuju puskesmas, pelayanan jalur pejalan kaki yang tidak ramah lansia sehingga mengganggu keamanan dan kenyamanan lansia untuk melintasinya, serta tidak tersedianya ruang parkir prioritas bagi lansia pada puskesmas. Dengan kondisi aksesibilitas fisik fasilitas puskesmas di Kota Yogyakarta tersebut, maka aksesibilitas fisik fasilitas puskesmas di Kota Yogyakarta tergolong sedang dalam mendukung penerapan konsep Age Friendly City. Hal ini mempengaruhi adanya penurunan kualitas akses penduduk lansia terhadap pelayanan fasilitas puskesmas yang akan menjadi kendala Kota Yogyakarta dalam menerapkan konsep Age Friendly City dan mewujudkan lansia yang aktif dalam memenuhi kebutuhan kesehatannya. Rekomendasi yang dapat digunakan untuk perencanaan selanjutnya dalam hal peningkatan kualitas pelayanan fasilitas puskesmas bagi lansia yaitu perlunya perbaikan akses pelayanan rute angkutan umum pada fasilitas puskesmas, letak lokasi halte, perbaikan kondisi jalur pejalan kaki dengan adanya penambahan marka jalur, penertiban PKL dan parkir kendaraan yang ada pada jalur pejalan kaki, serta menyediakan ruang parkir prioritas pada setiap sarana puskesmas. 
Desa-Kota, Vol. 3, No. 1, 2021, 1-16

\section{DAFTAR PUSTAKA}

BPS Kota Yogyakarta. (2014). Kota Yogyakarta dalam Angka Tahun 2014. Kota Yogyakarta: BPS. Diakses dari http://bit.ly/kotayogyakartadalamangka2014

BPS Kota Yogyakarta. (2020). Kota Yogyakarta dalam Angka Tahun 2019. Kota Yogyakarta: BPS. Diakses dari http://bit.ly/kotayogyakartadalamangka2020

Buchika, M. D., Erwan, K., Akhmadali. (2019). Studi Perencanaan Rute Angkutan Umum di Kota Pontianak. JeLAST, 5(2), 10. DOI: 10.26418/jelast.v5i2.25532

Budiman, R., \& Cahyono, A. B. (2017). Analisis Spasial Pelayanan Kesehatan Masyarakat terhadap Jumlah Pengunjung di Kota Blitar. Jurnal Teknik ITS, 6(2), C353-C356. DOI: 10.12962/j23373539.v6i2.23658

Daud, J. (2005). Studi Efektifitas Penggunaan Halte di Kota Medan (Studi Kasus : Koridor-koridor Utama Kota Medan). Jurnal Sistem Teknik Industri, 6(3). 73-80. Diakses dari http://repository.usu.ac.id/bitstream/handle/123456789/15901/sti-jul2005$\% 20 \% 2812 \% 29$.pdf? sequence=1\&isAllowed=y

Dewi, I. K., \& Saidah, E. D. (2017). Taman Kota Ramah Lansia untuk Mendukung Daya Tarik Pariwisata Kota Bogor (Kasus Studi : Taman Heulang). Prosiding Seminar Nasional Implementasi New Urban Agenda Melalui Pengembangan Pariwisata yang Berbasis Budaya Lokal dan Pemberdayaan Komunitas, Mataram-NTB, 14 September 2017, 113-121. Diakses dari https://www.researchgate.net/publication/322734404_Taman_Kota_Ramah_Lansia_Untuk_Mendukung_Daya_Tarik_Pariwisata_ Kota_Bogor_Kasus_Studi_Taman_Heulang

Dinas Kesehatan Pemerintah Kota Yogyakarta. (2019). Profil Kesehatan Tahun 2019 Kota Yogyakarta. Diakses dari https://kesehatan.jogjakota.go.id/uploads/profil2019data2018.pdf

Frans, A. J., Tondobala, L., \& Waani, J. O. (2016). Persepsi Pejalan Kaki terhadap Keamanan dan Kenyamanan Jalur Trotoar di Pusat Kota Amurang. Jurnal Arsitektur Daseng Unsrat, 5(2), 10-23. Diakses dari https://ejournal.unsrat.ac.id/index.php/daseng/article/view/14084

Hadi, P. L., Joewono, T. B., \& Santosa, W. (2013). Aksesibilitas Menuju Fasilitas Kesehatan di Kota Bandung. Jurnal Transportasi, 12(3), 213-222. DOI: 10.26593/jt.v13i3.1347.\%25p

Indrayani., \& Ronoatmodjo, S. (2018). Faktor-faktor yang Berhubungan dengan Kualitas Hidup Lansia di Desa Cipasung Kabupaten Kuningan Tahun 2017. Jurnal Kesehatan Reproduksi, 9(1), 69-78. DOI: 10.22435/kespro.v9i1.892.69-78

Katuk, M., \& Wowor, M. (2018). Hubungan Kemunduran Fisiologis dengan Tingkat Stress pada Lanjut Usia di Puskesmas Kakaskasen Kecamatan Tomohon Utara. Jurnal Keperawatan, 6(1), 1-7. Diakses dari https://ejournal.unsrat.ac.id/index.php/jkp/article/view/25181

Kementerian Kesehatan. (2015). Peraturan Menteri Kesehatan Nomor 67 Tahun 2015 tentang Penyelenggaraan Pelayanan Kesehatan Lanjut Usia di Pusat Kesehatan Masyarakat. Diakses dari https://persi.or.id/wp-content/uploads/2020/11/pmk672015.pdf

Kementerian Pekerjaan Umum dan Perumahan Rakyat. (2018). Surat Edaran Menteri Pekerjaan Umum dan Perumahan Rakyat Nomor 2 Tahun 2018 tentang Pedoman Perencanaan Teknis Fasilitas Pejalan Kaki. Diakses dari https://simantu.pu.go.id/personal/imgpost/197812092006042004/post/20190313135241_F_Pedoman_Fasilitas_Pejalan_Kaki.pdf

Kementerian Perhubungan. (2017). Peraturan Menteri Perhubungan Nomor PM 98 Tahun 2017 tentang Penyediaan Aksesibilitas pada Pelayanan Jasa Transportasi Publik bagi Pengguna Jasa Berkebutuhan Khusus. Diakses dari http://jdih.dephub.go.id/assets/uudocs/permen/2017/PM_98_TAHUN_2017.pdf

Kurnianto, D. (2015). Menjaga Kesehatan di Usia Lanjut. Jurnal Olahraga Prestasi, 11(2), 19-30. DOI: 10.21831/jorpres.v11i2.5725

Lathifah, N. N., \& Sadika, F. 2019. Perancangan Ulang Komponen Halte TMB Berdasarkan Kebutuhan Penyandang Disabilitas \{Studi Kasus Manusia Lanjut Usia (Lansia)\}. e-Proceeding of Art \& Design, 6(2). 3208-3219. Diakses dari https://openlibrarypublications.telkomuniversity.ac.id/index.php/artdesign/article/download/10264/10120

Massie, R. G. A. (2019). Akses Pelayanan Kesehatan yang Tersedia pada Penduduk Lanjut Usia Wilayah Perkotaan di Indonesia. Jurnal Penelitian dan Pengembangan Pelayanan Kesehatan, 3(1), 46-56. DOI: 10.22435/jpppk.v3i1.130

Pemerintah Kota Yogyakarta. (2013). Peraturan Walikota Yogyakarta Nomor 61 Tahun 2013 tentang Pelayanan Rumah Sehat Lansia di Kota Yogyakarta. Diakses dari https://peraturan.bpk.go.id/Home/Download/20034/Perwali\%20Yogyakarta\%20No.\%2061\%20 Tahun\%202013\%20ttg\%20Pelayanan\%20Rumah\%20Sehat\%20Lansia\%20di\%20Kota\%20Yogyakarta.pdf

Pemerintah Kota Yogyakarta. (2019). Keputusan Walikota Yogyakarta Nomor 450 Tahun 2019 tentang Roadmap Kota Yogyakarta Menuju Kota Ramah Lanjut Usia. Diakses dari https://hukum.jogjakota.go.id/asset/naskah/2020_01_21_11_10_38-174582996.pdf

Pemerintah Republik Indonesia. (2004). Peraturan Pemerintah Nomor 43 Tahun 2004 tentang Pelaksanaan Pelaksanaan Upaya Peningkatan Kesejahteraan Sosial Lanjut Usia. Diakses dari https://peraturan.bpk.go.id/Home/Download/56524/PP\%20No.43\%20TH\%202004.pdf

Setiyanti, U. (2019). Trotoar Ramah Lansia di Kecamatan Bogor Tengah Kota Bogor. JOM Bidang Perencanaan Wilayah \& Kota, 1(1), 1 6. Diakses dari https://jom.unpak.ac.id/index.php/teknikpwk/article/view/1159 
Desa-Kota, Vol. 3, No. 1, 2021, 1-16

Sitanggang, Y., Syarifuddin AS., \& Kadarini, S. N. (2018). Pengaruh Pedagang Kaki Lima terhadap Kenyamanan dalam Pemanfaatan Trotoar (Studi Kasus Jalan Jendral Urip Pontianak), JeLAST, 5(1), 1-15. DOI: 10.26418/jelast.v5i1.24155

Sri S, F.A., Vinsur, Elizabeth Y.Y., \& Sutiyarsih, E. (2019). Analisis Faktor yang Mempengaruhi Lansia Datang ke Pelayanan Kesehatan. Jurnal Ners dan Kebidanan, 6(2), 189-196. DOI: 10.26699/jnk.v6i2.ART.p189-196

SurveyMETER \& CAS UI. (2013). SATU LANGKAH MENUJU IMPIAN LANJUT USIA Kota Ramah Lanjut Usia 2030 Kota Yogyakarta. Sleman: SurveyMETER. Diakses dari https://media.neliti.com/media/publications/68-ID-satu-langkah-menuju-impian-lanjut-usiakota-ramah-lanjut-usia-2030-kota-mataram.pdf

Turel, H. S., True, E. M., \& Altug, I. (2007). Evaluation of elderly people's requirements in public open spaces : A case study in Bornova District (Izmir, Turkey). Building and Environment. 42(5), 2035-2045. DOI: 10.1016/j.buildenv.2006.03.004

Vibriyanti, D. (2018). Surabaya Menuju Kota Ramah Lansia: Peluang dan Tantangan. Jurnal Kependudukan Indonesia, 13(2), 117-132. Diakses dari https://journal.unnes.ac.id/sju/index.php/higeia/article/view/32746

WHO. (2007). Global Age-friendly Cities : A Guide. Geneva: WHO Library Cataloguing in Publication Data. Diakses dari https://www.who.int/ageing/publications/Global_age_friendly_cities_Guide_English.pdf

WHO. (2015). Measuring the Age-Friendliness of Cities: A Guide to Using Core Indicators. Japan: WHO Library Cataloguing in Publication Data. Diakses

https://apps.who.int/iris/bitstream/handle/10665/203830/9789241509695_esp.pdf;jsessionid=C7D4D66361AC2D9E5AEF730D72 9BB579? sequence $=1$ 